University of Montana

ScholarWorks at University of Montana

Spring 1991

\title{
An Explication and Test of Communication Network Content and Multiplexity as Predictors of Organizational Identification
}

\author{
Betsy Wackernagel Bach \\ University of Montana - Missoula, betsy.bach@umontana.edu \\ Connie Bullis \\ University of Utah, Salt Lake City, UT
}

Follow this and additional works at: https://scholarworks.umt.edu/communications_pubs

Part of the Communication Commons

Let us know how access to this document benefits you.

\section{Recommended Citation}

Wackernagel Bach, Betsy and Bullis, Connie, "An Explication and Test of Communication Network Content and Multiplexity as Predictors of Organizational Identification" (1991). Communication Studies Faculty Publications. 4.

https://scholarworks.umt.edu/communications_pubs/4

This Article is brought to you for free and open access by the Communication Studies at ScholarWorks at University of Montana. It has been accepted for inclusion in Communication Studies Faculty Publications by an authorized administrator of ScholarWorks at University of Montana. For more information, please contact

scholarworks@mso.umt.edu. 


\section{An Explication and Test of Communication Network Content and Multiplexity as Predictors of Organizational Identification}

\section{CONNIE BULLIS and BETSY WACKERNAGEL BACH}

Communication network research has been criticized for being based on an atheoretical method with little explanatory power. Research on organizational identification (OI), although theoretically rich, has been criticized for the paucity of research which examines the relationship between identification and communication. This research used OI as a theoretical framework from which to study communication networks. Incoming graduate students from three communication departments specified the content and patterns of their communication with members of their respective departments and indicated their organizational identification at three points in time during their first academic year. Results indicate that (a) multiplex communication relationships are positively associated with OI; (b) these respondents specified an array of ten content topics rather than the three traditionally used by network researchers; and (c) OI is related to specific conversational content. Academic talk during initial interactions was negatively related to midyear OI Mid-year social interaction and OI were positively related. Midyear interaction about departmental issues was negatively related to overall change in OI. Near the end of the first academic year, phatic and social topics were positively related to $O I$ while concrete interaction was negatively associated with change in OI.

$\mathrm{D}$ ESPITE THE POPULARITY OF communication network research, it has been criticized frequently as atheoretical. Lester (1981) argued that there have been surprisingly few attempts to integrate network constructs into coherent theoretical frameworks capable of explaining the causes and consequences of network involvement. Lester and Miller (1984) claimed that network research has taken place in a "theoretical vacuum" (p. 1). Hartman and Johnson (1989) concluded that network

CONNIE BULLIS (Ph.D., Purdue University, 1984) is Assistant Professor of Communication at the University of Utah, Salt Lake City, 84112. BETSY WACKERNAGEL BACH (Ph.D., University of Washington, 1985) is Associate Professor of Interpersonal Communication at the University of Montana, Missoula, 59812.

Portions of this paper were presented at the annual meeting of the Speech Communication Association, November, 1986 and the International Communication Association, May, 1989.

The authors are indebted to Kim Wells for her assistance with data collection and to Paul Bach for his review of the manuscript.

This study was supported by a grant from the University of Utah. 
research has failed to focus on organizational processes and suggested that network variables need to be linked with concepts such as role ambiguity and organizational commitment.

One difficulty in network research has been the identification of multiple (e.g., multiplex) network relationships. Burt (1983, p. 35) asserted "with the notable exception of ethnographers, network analysts rarely capture the complexity of naturally occurring relations." Traditionally, network research has emphasized communication structure rather than communication content (Burt \& Schott, 1985). The study of content has proven to be perplexing in network research, making it difficult to identify and dissect complex communication relationships.

In this study, we explore several shortcomings of communication network research. First, we provide a theoretical framework, organizational identification (OI) from which to study multiplex relationships. We then provide a method for analyzing, from the respondents' perspectives, the conversational content of network links. Finally, the relationship between conversational content and organizational identification is investigated.

\section{Organizational Identification}

Cheney (1983a, 1983b), Tompkins and Cheney (1983, 1985), and Cheney and Tompkins (1987) posited organizational identification (OI) as the basis of a rich, rhetorically-informed theory of organizational communication. OI is both a process and product involving the development of a relationship between individuals and organizations. They explained that although Kenneth Burke's (1950) and Herbert Simon's (1976) discussions of OI are different, they are complementary. Burke emphasized that individuals actively link themselves to elements in the social scene in order to compensate for the segregation they experience. This congregation/segregation dialectic is perhaps the fundamental dimension underlying human social life (Burke, 1950). Burke specified that employing organizations are natural targets for this identification process. Although Burke's primary interest was in explaining, understanding, and criticizing human relations, his theory is also useful for the purpose of understanding the development of individual-organizational relationships. The fundamental need to identify is integral to the assimilation process (Jablin, 1986).

The administrative perspective showed how organizations communicate routine organizational premises, judgments, and decisions that individuals employ in their daily organizational lives based upon factual and value premises of the organization (Simon, 1976). From this perspective, $\mathrm{OI}$ is viewed as a relationship that allows the organization to manage individual decision making through communication (Simon, 1976). When individuals identify with organizationally-oriented targets, and organizational decision premises are communicated to them, they make decisions that are best for the organization. 
Tompkins and Cheney (1985) developed their theory of unobtrusive control by integrating Burke's critical approach with Simon's functionalist approach and embedding their conceptualization of OI in an evolutionary, critical view of organizational control. As individuals identify more with organizational targets, they tend to adopt the organization's frame of reference, which increasingly narrows the individual's range of vision regarding decision situations and decision alternatives (Tompkins \& Cheney, 1985).

Organizations as whole entities may be the targets of individual identification. Identification with the whole organization is often viewed as a desirable goal (cf. Barnard, 1968; Tichy \& Devanna, 1986). However, Burke, Simon, and Tompkins and Cheney assumed that there are a variety of potential internal organizational (cf. Bullis \& Bach, 1989a), transorganizational (cf. Bullis, in press), and extra-organizational (cf. Cox, 1983) targets of identification. Some targets may complement one another while others may compete. Individuals adopt the frames of reference of those targets with which they most identify.

Several studies, summarized by Tompkins and Cheney (1985), have supported and elaborated upon this theory. Specifically, Laird and Hemphill (1983) supported the claim that OI is positively related to the perception of a narrower range of decision alternatives. Bullis and Tompkins (1989) supported the claim that OI is positively related to the use of organizationally-preferred decision premises in daily decision making. Paonessa (1983) discovered a relationship between OI and external organizational advocacy. Together, these studies point out the pragmatic significance of the theory. They suggest that OI has an impact on limiting the range of alternatives perceived in decision situations and that within the range of perceived alternatives, those who identify more highly, base decisions on those alternatives preferred by targets with which they identify. In other words, the relationship between OI and actual organizational decision making is supported. Moreover, it appears that OI is related to decisions that extend beyond the boundaries of the organization into informal decisions involving organizational advocacy which employees engage in outside of their organizational roles. OI is more than a theoretical "variable." Given these outcomes, it is important to continue to develop our understanding of the process of OI as it evolves through communication.

In order to carry on this work, Cheney (1982) argued that by examining OI at particular moments, we may view OI as a momentary product. This allows for a comparison of such moments over time as they relate to a variety of processes. For this immediate purpose. a defini. tion of OI is useful, although a definition does not capture the rich theory incorporated into the ongoing broader discussion of $\mathrm{OI}$ and unobtrusive control. Individuals are considered to identify with organizations to the extent that they feel a sense of belonging, membership, and similarity (Cheney, 1982). 
Four studies have highlighted specific communication practices related to OI. Cheney (1983b) discovered OI appeals in organizational messages. Verbal support at time of entry into the organization (Dionisopoulos \& Samter, 1983), oral communication of decision premises (Mills, 1984), and specific socialization turning point events (Bullis \& Bach, 1989b) have been associated with higher levels of OI. These studies suggest that particular, detailed communication practices and perceptions are related to OI. They need to be augmented by research that includes a more global view of individuals' communication patterns. The communication network tradition provides a method for such an examination. Through such work broader communication patterns in which individuals engage are discernable. At the same time, these broader patterns can be linked to and compared among individuals.

Previous researchers (Eisenberg, Monge, \& Miller, 1983; Sampugnaro, 1984) have employed network variables to examine the relationship between communication connectedness and organizational commitment, a concept that is closely related to identification (cf., Cheney \& Tompkins, 1987; Miller, Allen, Casey, \& Johnson, 1990; Mowday, Steers, \& Porter, 1979; Sass \& Canary, 1990). Eisenberg et al. (1983) discovered that the degree to which individuals were connected in workrelated networks was not directly associated with organizational commitment. Rather, the relationship between connectedness and commitment was more complex, depending upon job involvement and message content (Eisenberg et al., 1983; Sampugnaro, 1984). Specifically, Sampugnaro (1984) discovered a relationship between positive message content and organizational commitment. The simple degree of connectedness was not related to commitment; however, more careful probing of content revealed relationships. Similarly, Bach and Bullis (1986) discovered that network connectedness was not directly related to OI. In this study, we extend this research by examining multiplexity and communication content rather than examining only work-related interaction.

\section{Multiplexity}

A variety of topics unrelated to organizational tasks may flow through a single communication link (Albrecht \& Ropp, 1984). Although multiplexity has no definition upon which all completely agree (Minor, 1983), Verbrugge (1979) has asserted that whether defined by roles, behaviors, or affiliations, multiplexity refers to the multiple bases for communication in a dyad. Multiplexity is defined as the degree to which multiple contents flow through a dyadic link (Rogers \& Kincaid, 1981). Burt (1983, p. 37) suggested that "the relation of one person to another is multiplex to the extent that there is more than one type of relation between the first person and the second." 
Multiplexity, when combined with the study of job-related communication, should provide a better understanding of the substance of network relationships. It might also serve as a better predictor of OI than the job-related communication examined in extant work. Salancik and Pfeffer (1977) and White and Mitchell (1979) have argued that talk which occurs when one identifies with an organization includes more than just job-related interaction. Moreover, Stohl (1984) found multiplex relationships to be more enduring, intense, supportive, intimate, and influential than other relationships. We may anticipate that individuals should experience stronger OI to the extent that they form multiplex links within the organization.

\section{Multiplexity and Organizational Identification}

The connection between multiplex communication links and organizational identification is best viewed as a pattern that evolves through the developing individual-organizational relationship during the assimilation process. As newcomers enter organizations, they attempt to discover what constitutes organizational reality. One salient aspect of organizational reality, organizational values, is posited to be related to OI since values are used as decision premises. Newcomers seek to understand organizational values. Extant research (Siehl \& Martin, 1988) has supported the contention that newcomers learn organizational values over time. The use of organizational values in decision making has been related to OI (Bullis \& Tompkins, 1989). Organizational practices related to OI have been described (Kaufman, 1960; Simon, 1976), but from the perspective of the individual, this enculturation process remains a "black box" (Siehl \& Martin, 1988). An examination of network variables may help to specify this process.

Given our focus on the relationship between the individual and the organization, we are most interested in an aggregate or global understanding of the individuals' dyadic relationships. This assumes that individuals do not develop relationships directly with organizations but rather through their interactions with members of relevant organizations. On the other hand, Bullis and Bach (1989a) found that specific relationships with mentors did not link newcomers to organizations. This suggests that newcomers distinguish between particular dyadic relationships and relationships with "the organization." An aggregate examination of newcomers' communication with organizational members should better represent the individual relationship with the "organization."

Establishing multiplex communication links may have important implications for newcomer OI for two reasons. First, organizational value premises are subtly communicated to newcomers through their multiplex links. Multiplex contacts provide ample opportunity to 
exchange important messages. Hence, through multiplex links, a newcomer may have many opportunities to hear and adopt organizational decision premises. Additionally, newcomers may establish multiplex links with other organizational members to reduce the uncertainty inherent in developing individual-organization relationships. Powell (1990) indirectly argued for the importance of multiplexity when he claimed that trust and uncertainty reduction are related to network interaction.

Second, the degree to which a newcomer establishes multiplex links may affect OI because multiplex relationships are typically more influential (Kapferer, 1969; Wiemann, 1983). An individual may be more likely to adopt or conform to a message received from a strong multiplex link than to a message received from a weak, uniplex link (Bach, 1985; Mitchell, 1969). Newcomers who form multiplex relationships may develop higher levels of OI. In sum, the study of multiplexity and OI provides (a) the theoretical foundation from which to investigate multiplex network relationships, (b) a method for the study of communication patterns of identification, and (c) a perspective from which to assess the change in OI over time. Hence, our first hypothesis:

H1: Multiplexity is positively related to the development of organizational identification.

\section{Network Content}

A methodological problem arises when one attempts to study the content of information exchanged in multiplex communication networks. Communication network research has often employed a deductive perspective, assuming a limited range of content. This perspective may be related to the problems noted by critics of network research (Bernard \& Killworth, 1977; Bernard, Killworth, \& Sailer, 1979; Killworth \& Bernard, 1976; 1979), who have claimed "people do not know, with any accuracy, those with whom they communicate" (Bernard \& Killworth, 1977, p. 3).

In typical communication network studies, respondents are presented with a set of three categories in which to "code" the content of their conversations with others: (a) work-related (e.g., communication related to doing one's job; organizational policy and procedure), (b) social (e.g., family matters, personal concerns), or (c) innovative (e.g., new ideas; Farace, Monge, \& Russell, 1977). Respondents often find it difficult to distinguish between these three content areas. Stohl and Kakarigi (1985) found that these content distinctions are particularly ambiguous if (a) the content areas are not defined or are unclear, or if they occur (b) within the same relationship, (c) at the same time, or (d) in several different relationships. Bach (1989) found that when respondents were asked to code conversations about organizational policy innovations as either work-related or innovation-related, they had difficulty distinguishing between the 
two. In short, the difficulty respondents have in categorizing conversations into pre-existing categories may well lead to the inaccuracy reported by Bernard and Killworth. Moreover, Burt (1983) suggested that this causes measurement error and problems with validity. Burt and Schott (1985) noted potential increases in the likelihood of random errors in identifying the types of interaction that occur in a relationship.

Perhaps network researchers have inappropriately presumed knowledge of a finite set of a priori content categories in their study of network relationships. In a critique of network research methods, Richards (1981) asserted that if the respondents are allowed to specify the communication content of their relationships, the data are more likely to be valid. Elsewhere, Richards (1985) argued for the need to look at people's descriptions and interpretations of their own behavior.

The second purpose of our study is to ask respondents to specify the content of their communication. We assume that if respondents report communication content in their own terms, the categories derived from their reports will be less ambiguous and more relevant to the respondents and the organization(s) studied. Thus our first research question:

RQ1: What conversational content do organizational newcomers report?

\section{Conversational Content and Identification Over Time}

A third goal of this study is to investigate how conversational content and organizational identification mutually evolve during assimilation. As noted earlier, many studies have treated identification as a product rather than as both process and product. Adopting a longitudinal perspective permits observation of identification as the newcomerorganizational relationship evolves. However, capturing identification as a process is difficult because when the developing individualorganization relationship is reflected upon, "we tend to frame, reify, and instantiate it as to obscure processual development" (Cheney \& Tompkins, 1987, p. 9). Following Cheney and Tompkins (1987), in this study we "stop" the process and take several "snapshots" to describe the developing individual organization relationship rather than relying on a single "moment" or on the long-term memory of each participant.

Individual identification may be affected, in part, by the conversations one has with other organization members. Certain conversational content may lead to identification at certain points in time; topics that affect early stages of identification may be important at later stages. As such, organizational identification, as it occurs over time, may be affected by the content of conversations one has with other individuals. Hence, our second research question:

RQ2: Is the content of conversation related to organizational identification over time? 


\section{METHOD}

\section{Sample}

Respondents were 26 entering graduate students enrolled in masters or doctoral degree programs in three communication departments. The distribution of respondents by department was essentially equal $(8,9$, and 9 , respectively). Students were contacted during their first week of graduate school, asked to participate in the study throughout the academic year, and agreed. Initially 29 students volunteered: complete data were gathered from 26 students $(90 \%)$. They ranged in age from $23-55$ years $(\mathrm{X}=33.1, s=7.48)$. Approximately two-thirds $(65 \%)$ were women.

Academic departments were used for three reasons. First, Tompkins and Cheney's (1983) initial study of OI was conducted with graduate students. Subsequent research on graduate student OI has been fruitful (Bullis \& Bach, 1989a, 1989b). Second, by using groups of incoming graduate students, we could observe multiplex relationships as they were initiated and developed over time. Finally, the network structure in the academy typically is strongest within departments (Friedkin, 1978; Wilson, 1986). This allows for an examination of the department, rather than the entire organization, as an appropriate target of OI.

\section{Procedures}

Data were gathered during the second week of fall quarter, the second week of winter quarter, and the third week of spring quarter. There were approximately 14 weeks between these points of data collection. Instructions for completing the questionnaires were given at each point. Respondents were asked to complete and return the questionnaires within 48 hours. Assurances of confidentiality were made to each individual.

\section{Measurement and Data Analysis}

Organizational identification. Respondents were asked to report upon their identification with their academic department. OI was measured with a shortened, 17-item version of the Organizational Identification Questionnaire (OIQ) developed by Cheney (1982) and used in a number of studies (Bullis, 1984; Cheney, 1982; Cox, 1983; Mills, 1984). Internal reliability for the OIQ has averaged .94 using Cronbach's alpha (Bullis, 1984; Cheney, 1983a). The alpha coefficient for the 17-item version used in this study was .90. The OI score was calculated by summing the scores of the seventeen 7-point Likert-type questions and dividing by seventeen. Possible scores ranged from a minimum of one to a maximum of seven.

Change in identification. Because previous research (Bach \& Bullis, 1986) has discovered a relationship between individual propensity to 
identify and identification levels, it is important to examine change in identification over time in studies that purport to examine relationships between communication patterns and OI. This method controls for initial individual differences. The change in identification was measured by subtracting the initial OI score (fall quarter) from the final OI score (spring quarter).

Multiplexity. Multiplexity was assessed by presenting the newcomers with a roster (Farace et al., 1977; Richards, 1975, 1987) that included an alphabetical listing of all department members. Respondents were asked to identify those individuals with whom they had communicated during the previous two weeks. They were then asked to describe the essence(s) of their conversations with each person identified by responding to the open-ended question, "What did you talk about?"

While the methods for its operationalization are varied, in this study multiplexity was determined by assessing the structure of individual (e.g., ego-centered) networks (cf. Burt, 1983). The emphasis upon egocentered networks permits an in-depth analysis of who talks with whom and allows for an understanding of how this structure affects the developing individual-organization relationship (Wilson, 1986).

Following suggestions by Bach (1989), multiplexity was calculated as follows: First, for each newcomer, the number of content areas reported for each link in the network was tabulated. Next, the above score was divided by the total number of individuals with whom the newcomer communicated in order to determine an average score. For example, if a respondent reported talking with thirty-five others, the number of topics for the first, second, third, etc. through the thirty-fifth person was summed, and divided by thirty-five.

Conversational content. The responses to the open-ended question, which asked individuals to specify the content of their conversations, were analyzed qualitatively. Working independently, the researchers derived content categories using the "clustering technique" described by Miles and Huberman (1984). Categories were compared and collapsed into a single set of ten. Both researchers then independently coded the conversational content into these ten categories using the constant comparison method (Glaser, 1965), reaching an absolute agreement of .95. Reliability was computed using Cohen's (1960) kappa and found to be .94 .

Content categories and identification. To explore the relationship between conversational content and OI, six stepwise multiple regressions (SPSS, 1983) were calculated. Here, reported proportions of the $10 \mathrm{con}$ tent categories were regressed upon OI (see Table 1). First, content reported during fall quarter was regressed upon OI reported during fall quarter. Similarly, conversational content reported during winter quarter was regressed upon OI during winter. The same procedure was used to analyze data from spring quarter for the third regression. Regressions four and five tested the relationship between conversational 
TABLE 1

Predictor and Criterion Variables Used in Stepwise Multiple Regressions

\begin{tabular}{ccc}
\hline $\begin{array}{c}\text { Regression } \\
\text { Number }\end{array}$ & $\begin{array}{c}\text { Conversational Content } \\
\text { (Predictor) }\end{array}$ & $\begin{array}{c}\text { Organizational Identification } \\
\text { (Criterion) }\end{array}$ \\
\hline 1 & fall & fall \\
2 & winter & winter \\
3 & spring & spring \\
4 & fall & winter \\
5 & fall & spring \\
6 & winter & spring \\
\hline
\end{tabular}

content reported during fall quarter and OI during winter and spring respectively. Finally, conversational content from winter quarter was regressed upon identification reported during spring. Additionally, the conversational content from fall, winter, and spring quarters were regressed upon the change in identification in three separate regressions.

\section{RESULTS}

\section{Hypothesis One}

The first hypothesis was supported. When multiplexity scores from autumn quarter were regressed upon OI, multiplexity was a significant positive predictor of change in organizational identification over time $\left(\mathrm{r}=.44, \mathrm{p}<.05 ; \mathrm{r}^{2}=.19\right)$.

\section{Research Question One}

Individuals specified ten different categories of conversational content. Table 2 displays these results. A description of these categories follows.

Departmental issues. Approximately $6 \%$ of the conversational content included (a) the department, (b) specific professors or peers, and (c) department politics. The content specified was primarily social yet emphasized the learning of departmental rules. One graduate student noted that "We talked about the program and people in the department," while a second stated that she "talked about GSA (the graduate student association) and how previous grads had fared" (see Table 2).

Academic content. Eleven percent of the content involved the exchange of knowledge or information. Individuals typically discussed concepts introduced in class, sought information about a class assignment, or talked about their research projects. Responses such as "I asked him for more information on our next paper," and "We talked about our common interest in health communication," were typical of this category. 
TABLE 2

Descriptive Data Comparing Waves on Link Content Data

\begin{tabular}{|c|c|c|c|c|c|c|c|}
\hline & Fall & & Winter & & Spring & & \\
\hline n & $\begin{array}{c}\% \text { of } \\
\text { Total Links }\end{array}$ & $\mathrm{n}$ & $\begin{array}{c}\% \text { of } \\
\text { Total Links }\end{array}$ & $\mathrm{n}$ & $\begin{array}{c}\% \text { of } \\
\text { Total Links }\end{array}$ & TOTAL & TOTAL \% \\
\hline
\end{tabular}

\begin{tabular}{|c|c|c|c|c|c|c|c|c|}
\hline $\begin{array}{l}\text { Departmental } \\
\text { Issues }\end{array}$ & 85 & .06 & 50 & .05 & 43 & .05 & 178 & .06 \\
\hline Academic & & & & & & & & \\
\hline $\begin{array}{l}\text { Content } \\
\text { Academic }\end{array}$ & 137 & .10 & 100 & 11 & 104 & .13 & 341 & .11 \\
\hline $\begin{array}{l}\text { Survival } \\
\text { Concrete }\end{array}$ & 115 & .08 & 47 & 05 & 86 & .10 & 248 & .08 \\
\hline Topics & 259 & .20 & 146 & .16 & 159 & .20 & 564 & .18 \\
\hline $\begin{array}{l}\text { Phatic Com- } \\
\text { munication }\end{array}$ & 34 & .0 .3 & 84 & .09 & 52 & .06 & 170 & .06 \\
\hline $\begin{array}{l}\text { Social Com- } \\
\text { munication } \\
\text { Personal }\end{array}$ & 337 & .26 & 207 & .22 & 146 & .18 & 690 & .23 \\
\hline $\begin{array}{l}\text { Issues } \\
\text { Philosophical }\end{array}$ & 109 & .08 & 91 & .10 & 85 & .10 & 285 & .09 \\
\hline Issues & 41 & .03 & 14 & .01 & 15 & .02 & 70 & .02 \\
\hline General Sehool & 140 & .11 & 165 & .18 & 111 & .14 & 416 & .14 \\
\hline MISC & 41 & .03 & 34 & .04 & 14 & .02 & 89 & .03 \\
\hline TOTAL & 1298 & (.43) & 938 & (.30) & 815 & $(.27)$ & & \\
\hline
\end{tabular}

Academic survival. Academic survival comprised $8 \%$ of the total talk. These conversations were future-oriented and entailed the identification of strategies and tactics for "getting through the program." As one newcomer noted, "He asked me how I was doing and if I'd be able to make it through the program."

Concrete topics. Eighteen percent of the conversations were characterized by a need for immediate information and advice about daily activities. Requests for help in debriefing a class activity, how to get output from a computer terminal, and advice for how to handle a problem student were typical. Respondents reported information such as "We talked in detail about how to grade speech performance," and "I wondered about how to register."

Phatic communication. Non-intimate and surface greetings, hellos, and chit-chat were coded as phatic communication and comprised $6 \%$ of the total talk. Characteristic of the conversations here were, "We exchanged a 'general hello'," and "We exchanged brief greetings in the hall."

Social. Twenty-three percent of the communication was social. These conversations were non-intimate, trivial in nature, and not related to departmental issues. Discussions about current movies, skiing, food, and beer were typical. Social conversations included, "We talked about Chinese cuisine," and "I asked about his salmon fishing trip." 
Personal issues. These conversations were generally disclosive about past experiences, family, and finances, accounting for $9 \%$ of all communication. As one student noted, "I explained how difficult it was for me to return to graduate school and listened to her encouragement."

Philosophical issues. Philosophical issues comprised $2 \%$ of communication. Feminism, sexism, religion, and morality were discussed in conversations such as, "We talked about God and Eastern religion," and "We talked in detail about our choice of lifestyle."

School. Fourteen percent of all conversations were about generic, school-related topics such as "school" or "class." More specific instances of school or class were coded into other categories.

Miscellaneous. The $3 \%$ of conversations which did not fit into the other nine categories were coded miscellaneous. Typical responses were non-specific accounts, such as "We talked about everything."

\section{Research Question Two}

We explored the relationship between the conversational content categories and the process of organizational identification. The regression analysis resulted in several relationships. Talk about academic content, social topics, phatic communication, departmental issues, and concrete topics were related to OI at several points in time.

Fall quarter. When the content categories from fall quarter were regressed upon $O I$ fall quarter, no variables entered into the regression equation. However, when the content categories fall quarter were regressed upon OI levels winter quarter, academic content was a negative predictor of $\mathrm{OI}\left(\mathrm{r}=-.41, \mathrm{p}<.05 ; \mathrm{r}^{2}=.17\right)$. Higher proportions of academic content talk predicted lower $\mathrm{OI}$.

Winter quarter. During winter quarter, communication about social topics was positively related to identification winter quarter $(\mathrm{r}=.64$, $p<.0001 ; r^{2}=.41$ ). Additionally, evidence of communication about departmental issues during winter was negatively related to overall change in identification $\left(\mathrm{r}=-.47, \mathrm{p}<.05 ; \mathrm{r}^{2}=.22\right)$.

Spring quarter. When entered into a regression equation, phatic communication during spring quarter was positively related to OI during spring quarter $\left(\mathrm{r}=.54, \mathrm{p}<.01 ; \mathrm{r}^{2}=.29\right)$. Concrete topics during spring quarter was negatively related to overall change in identification ( $r=$ $-.48, \mathrm{p}<.05 ; \mathrm{r}^{2}=.23$ ).

\section{DISCUSSION}

Our purposes in this study were to: (a) explore the relationship between multiplex communication links and the developing individualorganization relationship, (b) examine conversational content generated by newcomers as they experience the assimilation process, and (c) explore how specific conversational content is related to OI. The study was exploratory and the interpretations offered here must be considered within the limitations of exploratory work. The small sample size, 
graduate student population, and modest effect sizes make caution particularly important in how these interpretations are used in future work.

However, several implications can be drawn from the results. First, the establishment of multiplex relationships predicts change in OI. Irrespective of initial OI, stronger initial multiplexity predicts the growth in OI over the first academic year. Hence, multiplexity appears central to the process of OI since individuals who have higher degrees of participation may be more affected by organizational decision premises (cf. Hartman \& Johnson, 1989). This finding broadens extant work by elaborating upon a global pattern of communicative interaction as it related to OI. It supports earlier research which suggests that simply more connections in a job-related network (or in general) do not directly relate to OI. Rather, the range of diversity of connections an individual tends to experience with others is related to OI. This finding echoes current calls for viewing communication as a rich, complex, identity-related phenomenon as opposed to a relational tool or conduit through which unitary clear messages flow. It also implies support for views that espouse the end of assumed "innocence" in our views of communication. In other words, as rich, diverse (i.e., multiplex), interactions occur, relationships develop, identities are shaped, and influence is exerted. This influence process needs to be made explicitly, and not assumed to be neutral. Multiplex relationships between individuals and organizational targets may be interpreted as one of the "subtle, elusive" (Tompkins \& Cheney, 1985) communication patterns through which individuals, striving to overcome segregation by congregating, participate in their own indoctrination. In other words, as individuals create multiplex relationships that extend beyond task-related interaction, they may be simultaneously extending organizational influence. This interpretation is supported by the findings that social topics were (at some particular points in time) related to OI while task-related topics (at some particular points in time) were negatively related to OI.

While this study has focused on multiplexity as it is related to OI, it implies that multiplexity should be examined as an explanatory network variable. It may be useful in unraveling other research perplexities which have arisen by focusing on a particular type of network.

Next, when encouraged to specify the content of their communication with others, respondents provide a more diverse array of content than traditionally used in network research. Richards (1981) suggested that if respondents specify the communication content of their linkages, the data are more likely to provide valid results. Results of this study illustrate that respondents are able to generate information which can be used in network analysis. Because respondent-generated categories may decrease the problem of ambiguity as respondents select among researcher-generated alternatives, this method should increase validity of network research and begin to answer some of the criticisms raised about the accuracy of network data. 
Respondent-generated categories also allow for a more complete account of life in the organization studied. At a time when the study of organizational culture is important (Smircich \& Calas, 1987), this approach allows for the study of conversational content in particular organizations. Phenomenologically generated categories can be replete with jargon, argot, and laden with organizational values. Hence, these content categories provide a description of what is important to organizational members. For example, respondents from one department reported talking about being a "community of scholars," a departmental value that was expressed to incoming graduate students. The implication here is potentially important to network research. These results suggest the importance of asking respondents to specify the content of their interactions. This is consistent with recent work (Corman, 1990) that argues that network research is valuable not for its ability to discover collective communication structure but as a measure of members' perceptions. It is sensible to examine members' perceptions of content as well as the forms of linkages.

Finally, several respondent-generated content categories predict OI. OI at specific points in time was affected by different types of conversational content. Although these results are irregular in that no specific content consistently predicted OI over three points in time, the results do suggest that $\mathrm{OI}$ is fostered through a variety of conversational topics. Social interaction appears to be important, at least at some particular points in time. Several task-related topics were negatively related to OI at particular points. Different conversational content is important as the developing individual-organization relationship unfolds over time. At the same time, the process is too complex to be reduced to any particular content. Taken with the multiplexity finding, we may interpret these results to indicate that the degree of variety of communication content is more consistently related to OI than is any particular content.

While the results of this study are encouraging, they should be interpreted with some caution for several reasons. First, the size of the sample is small. Second, the nature of the sample does not allow for clear generalization. Incoming communication graduate students could have been exposed to the research topic. Such prior knowledge could have affected their reported OI. Additionally, because the respondents were graduate students, the results are not generalizable. Finally, most of the effect sizes for the reported significant results were small, ranging from .17 to .41 .

Several extensions of this study are needed, in addition to the obvious need for replication. First, the generalizability of conversational content categories should be tested. The categories seem to have face validity across organizations and conversations. On the other hand, Monge and Eisenberg (1987) argued that content is context-specific. To discover both generalizable and context-specific content, a variety of populations should be studied. Subsequent research should also 
concentrate on organizational veterans. A study comparing multiplexity between veterans and newcomers could test how communication network involvement is related to stage of assimilation.

Second, the method employed here to use respondent-generated categories should be further tested to determine whether it is indeed useful in increasing respondent accuracy. Given the current interest in this issue, this method could be used to determine whether it results in greater respondent accuracy, or whether as Corman (1990) argued, respondent accuracy should not be expected of network research.

Continued refinement and extension of the multiplexity and OI measures used here are needed to further clarify the relationship between the two constructs. Discourse analysis could reveal discussions of values that occur in diverse conversations. Given the importance of decision making to identification, decision premises should be examined as an additional measure of identification. Changes in individuals' preferred premises as a function of network involvement, multiplexity, and assimilation stages could also be explored. The stability and change of interests represented in such premises should be examined.

Continued probing of specific network and OI patterns is needed. Comparative studies are needed to determine whether organizations differ. Organizational level network structures should be compared. Ad. ditional probing of newcomer communication with various groups such as new peers, veterans, subcultural groups, and competing targets of identification is warranted. In future work, the posited linkages between social interaction as well as multiplexity and OI implies that the examination of only job-related communication should be questioned in future work. Finally, the implied linkage between multiplexity, OI, and unobtrusive control should be investigated. Future explorations should examine whether and how premises flow through multiplex links and are subsequently employed in internal and external organizational decision making.

\section{REFERENCES}

Albrecht, T. L., \& Ropp, V. A. (1984). Communicating about innovation in networks of three U.S. organizations. Journal of Communication, 34 (3), 78-91.

Bach, B. W. (1985). Relationship multiplexity as a predictor of individual innovation adoption. Unpublished doctoral dissertation, University of Washington.

Bach, B. W. (1989). The effect of multiplex relationships upon innovation adoption: A reconsideration of Rogers' model. Communication Monographs, 56, 133-150.

Bach, B. W., \& Bultis, C. (1986, November). The relationship between organizational identification and network involvement: A preliminary investigation. Paper presented to the annual meeting of the Speech Communication Association, Chicago.

Bernard, H. R., \& Killworth, P. D. (1977). Informant accuracy in social network data II. Human Communication Research, 4, 3-18.

Bernard, H. R., Killworth, P. D., \& Sailer, L. (1979). Informant accuracy in social network data IV: A comparison of clique-level structure in behavioral and cognitive network data. Social Networks, 2, 191-218.

Bullis, C. A. (1984). The forest ranger revisited. Unpublished doctoral dissertation, Purdue University. 
Bullis, C. A. (in press). Organizational values and control: The case of professionals in the U.S. Forest Service. In C. Conrad (Ed.), The ethical nexus: Values and decisionmaking in organizations. New York: Ablex.

Bullis, C. A., \& Bach, B. W. (1987, November). Organizational identification in an academic setting: A comparative study. Presented to the annual meeting of the Speech Communication Association, Boston.

Bullis, C., \& Bach, B. W. (1989a). Are mentor relationships helping organizations? An exploration of developing mentee-mentor-organizational identifications using turning point analysis. Communication Quarterly, 37, 199-213.

Bullis, C., \& Bach, B. W. (1989b). Socialization turning points: An examination of change in organizational identification. The Western Journal of Speech Communication, $53,273-293$.

Bullis, C. A., \& Tompkins, P. K. (1989). The forest ranger revisited: A study of control practices and identification. Communication Monographs, 56, 287-306.

Burke, K. (1969). A rhetoric of motives. Berkeley, CA: University of California Press. (Originally published 1950 ).

Burt, R. S. (1983). Distinguishing relational contents. In R. S. Burt and M. J. Minor (Eds.), Applied network analysis: A methodological introduction (pp. 35-74). Beverly Hills, CA: Sage.

Burt, R. S., \& Schott, T. (1985). Relation contents in multiple networks. Social Science Research, 14, 287-308.

Cheney, G. (1982). Organizational identification as a process and product: A field study. Unpublished master's thesis, Purdue University.

Cheney, G. (1983a). On the various and changing meanings of organizational membership: A field study of organizational identification. Communication Monographs, $50,342-362$.

Cheney, G. (1983b). The rhetoric of identification and the study of organizational communication. Quarterly Journal of Speech, 69, 143-158.

Cheney, G., \& Tompkins, P. (1987). Coming to terms with organizational identification and commitment. Central States Speech Journal, 38, 1-15.

Cohen, J. (1960). A coefficient of agreement for nominal scales. Educational and Psychological Measurement, 20,37-46.

Corman, S. R. (1990). A model of perceived communication in collective networks. Human Communication Research, 16, 582-602.

Cox, M. (1983). The effects of Black identification on organizational identification on com. munication supportiveness. Unpublished doctoral dissertation. Purdue University.

Dionisopoulos, G., \& Samter, W. E. (1983, May). Identification by anthesis: An analysis of the "us versus them" orientation by police. Presented at the annual meeting of the Eastern Communication Association, Ocean City, MD.

Eisenberg, E. M., Monge, P. R., \& Miller, K. I. (1983). Involvement in communication networks as a predictor of organizational commitment. Human Communication Research, 10, 179-201.

Farace, R. V., Monge, P. R., \& Russell, H. M. (1977). Communicating and organizing. New York: Random House.

Friedkin, N. E. (1978). University social structure and social networks among scientists. American Journal of Sociology, 83, 1444-1465.

Glaser, B. G. (1965). The constant comparative method of qualitative analysis. Social Problems, 12, 436-455.

Hartman, R. L., \& Johnson, J. D. (1989). Social contagion and multiplexity: Communication networks as predictors of commitment and role ambiguity. Human Communication Research, 15, 523-548.

Jablin, F. (1986, May). What is organizational assimilation? An overview of communication, socialization, and individualization processes. In L. Putnam (Chair), Communication and organizational socialization. Pre-conference conducted at the meeting of the International Communication Association, Chicago.

Kapferer, B. (1969). Norms and the manipulation of relationships in a work context. In J. C. Mitchell (Ed.), Social networks in urban situations: Analyses of personal 
relationships in central African homes (pp. 181-244). Manchester, England: Manchester University Press.

Kaufman, H. (1960). The forest ranger: A study in administrative behavior. Baltimore: Johns Hopkins Press.

Killworth, P. D., \& Bernard, H. R. (1976). Informant accuracy in social network data. Human Organization, 35, 269-286.

Killworth, P. D., \& Bernard, H. R. (1979). Informant accuracy in social network data III: A comparison of triadic structure in behavioral and cognitive data. Social Networks. $2,10-46$.

Laird, A., \& Hemphill, M. R. (1983, November). The relationship between identification and evaluation in organizational decision making. Paper presented at the annual meeting of the Speech Communication Association, Washington, D.C

Lester, R. E. (1981, February). Embedding network analysis constructs in a theoretical framework: A preliminary formulation of a model of intraorganizational communication behavior. Presented at the annual meeting of the Western Speech Communication Association, San Jose, CA.

Lester, R. E., \& Willer, L. R. (1984, May). Determinants and consequences of organizational communication network patterns: A theoretical formulation and exploratory pilot study. Presented at the annual meeting of the International Communication Association, San Francisco.

Miles, M. B., \& Huberman, M. A. (1984). Qualitative data analysis: A sourcebook of new methods. Beverly Hills, CA: Sage.

Miller, V., Allen, M., Casey, M., \& Johnson, J. R. (1990, June). A factor analytic investigation of the organizational idenification questionnaire instrument. Paper presented at the annual meeting of the International Communication Association, Dublin.

Mills, J. (1984). Unobtrusive control and communication in organizations: A field study. Unpublished manuscript, Purdue University.

Minor, M. J. (1983). New directions in multiplexity analysis. In R. S. Burt \& M. J. Minor (Eds.), Applied network analysis: A methodological introduction (pp. 223-244). Beverly Hills, CA: Sage.

Mitchell, J. C. (1969). The concept and use of social networks. In J. C. Mitchell (Ed.), Social networks in urban situations: Analyses of personal relationships in central African towns (pp. 1-50). Manchester, England: Manchester University Press.

Monge, P. R., \& Eisenberg, E. M. (1987). Emergent communication networks. In F. M. Jablin, L. L. Putnam, K. H. Roberts, \& L. W. Porter (Eds.), Handbook of organizational communication (pp. 304-342). Newbury Park, CA: Sage.

Mowday, R. T., Steers, R. M., \& Porter, L. W. (1979). The measurement of organizational commitment. Journal of Vocational Behavior, 14, 224-247.

Paonessa, K. A. (1983). Corporate advocacy and organizational member identification: A base study of General Motors. Unpublished Master's thesis, Purdue University.

Powell, W. W. (1990). Neither market nor hierarchy: Network forms of organization. Research in Organizational Behavior, 12, 295-336.

Putnam, L. L., \& Pacanowsky, M. E. (Eds.). (1983). Communication and organizations: An interpretive approach. Beverly Hills, CA: Sage.

Richards, W. D. (1975). A manual for network analysis using the NEGOPY netuork analysis program. Institute for Communication Research, Stanford University.

Richards, W. D. (1981). Getting data for network analysis: What's really happening here, anyway? Unpublished manuscript, Simon Fraser University.

Richards, W. D. (1985). Data, models, and assumptions in network analysis. In R. D. McPhee \& P. K. Tompkins (Eds.), Organizational communication: Traditional themes and new directions (pp. 109-128). Beverly Hills, CA: Sage.

Richards, W. D. (1987). Network analysis in organizations. Unpublished manuscript, Simon Fraser University.

Rogers, E. M. (1987). Progress, problems, and prospects for network research: Investigating relationships in the age of electronic communication technologies. Social Networks, 9, 285-310.

Rogers, E. M., \& Kincaid, D. L. (1981). Communication networks: Toward a new paradigm for research. New York: Free Press. 
Salancik, G. R., \& Pfeffer, J. (1977). An examination of need-satisfaction models of job attitudes. Administrative Science Quarterly, 22, 427-456.

Sampugnaro, V. (1984). Network message content as a predictor of organizational commit. ment. Unpublished master's thesis. Purdue University.

Sass, J. S., \& Canary, D. J. (1990, November). Organizational commitment and identification: An examination of conceptual and empirical convergence. Paper presented to the annual meeting of the Speech Communication Association, Chicago.

Siehl, C., \& Martin, J. (1988). Measuring organizational culture: Mixing qualitative and quantitative methods. In M. O. Jones, M. D. Moore, \& R. C. Snyder (Eds.), Inside organizations: Understanding the human dimension (pp. 79-103). Newbury Park, CA: Sage.

Simon, H. A. (1976). Administrative behavior: A study of decision-making in administrative organization (3rd ed.). New York: The Free Press.

Smircich, L., \& Calas, M. B. (1987). Organizational culture: A critical assessment. In F. M. Jablin, L. L. Putnam, K. H. Roberts, \& L. W. Porter (Eds.), Handbook of organizational communication: An interdisciplinary perspective (pp. 228-263). Newbury Park, CA: Sage.

SPSS Inc. (1983). SPSSX user's guide. New York: McGraw-Hill.

Stohl, C. (1984, November). The impact of social networks and the development of communicative competence. Presented to the annual meeting of the Speech Communication Association, Chicago.

Stohl, C., \& Kakarigi, D. (1985, November). The NEGOPY network analysis program: A critical appraisal. Presented to the annual meeting of the Speech Communication Association, Denver.

Tichy, N. M., \& Devanna, M. A. (1986). The transformational leader. New York: John Wiley and Sons.

Tompkins, P. K.. \& Cheney, G. (1983). Account analysis in organizations: Decision making and identification. In L. L. Putnam \& M. E. Pacanowsky (Eds.), Communication and organizations: An interpretive approach (pp. 123-146). Beverly Hills, CA: Sage.

Tompkins, P. K., \& Cheney, G. (1985). Communication and unobtrusive control in contemporary organizations. In R. D. McPhee \& P. K. Tompkins (Eds.), Organizational communication: Traditional themes and new directions (pp. 179-210). Beverly Hills, CA: Sage.

Verbrugge L. M. (1979). Multiplexity in adult friendships. Social Forces, 57, 1286-1309.

White, S. E., \& Mitchell, T. R. (1979). Job enrichment versus social cues: A comparison and competitive test. Journal of Applied Psychology, 64, 1-9.

Wiemann, G. (1983). The strength of weals conversational ties in the flow of information and influence. Social Networks, 5, 245-267.

Wilson, A. (1986, November). Organizational identification and work-related networks: A preliminary investigation of a "multiplex" relationship. Presented to the annual meeting of the Speech Communication Association, Chicago. 
Copyright of Western Journal of Speech Communication: WJSC is the property of Western States Communication Association and its content may not be copied or emailed to multiple sites or posted to a listserv without the copyright holder's express written permission. However, users may print, download, or email articles for individual use. 